\title{
General practitioners' attitudes towards AIDS and their perceived information needs
}

\author{
Jonathan A Shapiro
}

\begin{abstract}
A short questionnaire on general practitioners' self perceived and actual knowledge of AIDS and their attitudes to the illness was sent to 1824 general practitioners throughout the United Kingdom. The rate of response was $\mathbf{7 0} \%$. Women doctors, those who trained overseas, and those who were married tended to have less positive attitudes towards patients with HIV and AIDS, whereas younger doctors, trainers, and members of the Royal College of General Practitioners were more understanding, better informed, and had more positive attitudes. Doctors with the least knowledge about HIV and AIDS and the most negative attitudes towards the illness would benefit from further education, which would be most effectively delivered through the professional journals, the Department of Health, and the charitable AIDS organisations.
\end{abstract}

\section{Introduction}

AIDS raises many important issues for general practitioners. The care of patients positive for HIV, confidentiality, and risk to doctors have all been discussed, but solutions have not readily been forthcoming. General practitioners already deliver messages of disease prevention and health promotion effectively, ${ }^{1}$ and there is no reason why they should differ with respect to AIDS. Before any educative work can start, however, the standpoint of potential educators must be established. Little large scale work has been done in the United Kingdom about the attitudes of general practitioners to AIDS. Indeed, the lay press suggests that doctors' attitudes towards the disease may be as negative as those of most of the public. ${ }^{2}$

Small scale studies have been carried out, ${ }^{3.6}$ and the Department of Health is funding a study over several years, but there have been no surveys of a nationwide sample of general practitioners. Hence I performed a questionnaire study to establish a national baseline of attitudes and knowledge about HIV and AIDS among general practitioners. This would help in identifying those groups of doctors who would benefit most from further education about the condition, planning packages to educate those doctors, and measuring changes over time.

General Practice Unit, Department of Community Health, University of Leicester, Clinical Sciences Building, Leicester Royal Infirmary, Box 65, Leicester LE2 7LX Jonathan A Shapiro, MRCGP, clinical lecturer in general practice

BrMed f 1989;298:1563-6 week out of date. To maximise rates of response and allow the survey to be carried out quickly, a single card questionnaire was used with questions on one half separated from the answers by perforations. Thus the answers could be returned, reply paid and without an envelope, without compromising confidentiality.

The questionnaire had five sections. The first sought demographic details of the respondents, including a classification of their practice, sex, marital state, training state, membership of the Royal College of General Practitioners, and details of where and when they had qualified. Next were questions about how many patients with HIV or AIDS they had seen. In the third section there were 10 questions testing their attitudes to HIV and AIDS. The fourth section asked where general practitioners currently obtained their information about HIV and what sources they would like to use. Finally, six questions ascertained the actual knowledge of the respondents for comparison with their self perceived knowledge.

The questionnaires were sent out with a covering letter, and five weeks were allowed for the replies. After that another copy of the questionnaire in a different colour was sent with a reminder letter to nonrespondents. Another month was allowed before the data were analysed. A second reminder was thought not to be worth while on the basis of the low response to the first.

\section{Results}

A total of 1824 questionnaires were sent out, of which 1271 were returned, a response rate of $70 \%$. For each question invalid answers were discounted before the data were analysed unless stated otherwise.

The survey aimed at ascertaining the views of a representative set of general practitioners. The replies suggested that the respondents were typical in terms of whether they were members of the Royal College of General Practitioners $(483,38.0 \%)$, were trainers (144, $11 \cdot 3 \%)^{7}$ and worked in an urban environment (644 $(50.7 \%)$ in inner city or other urban practices by the respondents' own definitions). ${ }^{8}$ Altogether 1143 $(91 \cdot 1 \%)$ doctors had trained in United Kingdom medical schools, $33(2 \cdot 6 \%)$ in European medical schools, $4(0.3 \%)$ in the Americas, and $74(5.9 \%)$ in the Third World. The total of foreign graduates was therefore $111(8 \cdot 8 \%)$, whereas around $20 \%$ of practising general practitioners graduated abroad (Overseas Doctors' Association, personal communication). Women were overrepresented in the replies (305, $24 \%$ ), the accepted figure for the proportion of unrestricted principals who are women being $18 \%{ }^{8}{ }^{8}$

Doctors were asked whether they had had any professional contact with patients positive for HIV and those with AIDS and if so how many. Table I shows the answers related to the location of the practice.

Six questions were set to test factual knowledge about HIV and AIDS. For five questions respondents had to say whether a statement was true or false and one question required a one of eight response. Table 
II shows the questions and results. The results were combined into a knowledge score (two marks for a correct answer, one for a don't know, and none for a wrong response). In the final question two marks were allocated if the answer was right, one if it was within one range of the correct answer, and none if it was completely wrong.

To analyse which of the demographic variables were associated with knowledge about HIV a stepwise multiple regression was used. The dependent variable was the knowledge score, and the independent variables were sex, marital state, type of practice, training state, membership of the royal college, and place and year of qualification. As the distributions of the numbers of patients with AIDS and patients positive for HIV seen were both highly skewed the natural logarithms of these figures were used as independent variables. The factors found to be significantly associated with the knowledge score were year of qualification at a United Kingdom medical school, the natural logarithm of the number of patients positive for HIV seen, and training state. Table III shows the partial regression coefficients, their standard errors, and the probability of their being significantly different from zero.

Respondents were asked to name their most impor- tant sources of information about HIV and AIDS and suggest other sources that might be useful. The named sources were professional journals (341 doctors), Department of Health circulars (233), unclassified sources (194), medical meetings (147), free medical publications (116), television programmes (63), and other sources (92).

Table IV lists the responses to the 10 additional questions. They were analysed by ordered polytomous logistic regression, a technique that relates an ordered categorical dependent variable to categorical and continuous independent variables. This was performed with the LOGIST procedure of the SAS computer package. The attitudes were scored 0-4 (agreedisagree), and the independent variables were entered into the model in a stepwise procedure. Each result is accompanied by the Wald statistic and its $p$ value. Under the null hypothesis that the partial regression coefficient for the variable is zero this statistic has a $\chi^{2}$ distribution with one degree of freedom. Table $\mathrm{V}$ shows the significant results of this analysis.

\section{Discussion}

The knowledge questions tested not only factual knowledge but also doctors' interest in AIDS. They

TABLE I-Relation between classification of practice and number of patients positive for HIV and with AIDS seen. Figures are numbers (percentages) of doctors

\begin{tabular}{|c|c|c|c|c|c|c|c|c|c|c|c|}
\hline \multirow[b]{3}{*}{ Type of practice } & \multicolumn{6}{|c|}{ HIV } & \multicolumn{5}{|c|}{ AIDS } \\
\hline & \multirow{2}{*}{$\begin{array}{l}\text { No }(\%) \text { of } \\
\text { practices } \\
\text { responding }\end{array}$} & \multicolumn{5}{|c|}{ No of patients seen } & \multirow{2}{*}{$\begin{array}{l}\text { No (\%) of } \\
\text { practices } \\
\text { responding }\end{array}$} & \multicolumn{4}{|c|}{ No of patients seen } \\
\hline & & 0 & 1 & 2 & 3 & $>3$ & & 0 & 1 & 2 & $>2$ \\
\hline Inner city & $199(16 \cdot 0)$ & $88(44 \cdot 2)$ & $32(16 \cdot 1)$ & $18(9 \cdot 0)$ & $13(6 \cdot 5)$ & $48(24 \cdot 2)$ & $200(16 \cdot 2)$ & $135(67 \cdot 5)$ & $31(15 \cdot 5)$ & $14(7 \cdot 0)$ & $20(10 \cdot 0)$ \\
\hline Other urban & $433(34 \cdot 7)$ & $316(73.0)$ & $61(14 \cdot 1)$ & $26(6 \cdot 0)$ & $12(2 \cdot 8)$ & $18(4 \cdot 1)$ & $429(34 \cdot 7)$ & $370(86 \cdot 2)$ & $44(10 \cdot 3)$ & $10(2 \cdot 3)$ & $5(1 \cdot 2)$ \\
\hline Mixed village-urban & $450(36 \cdot 1)$ & $332(73 \cdot 8)$ & $83(18 \cdot 4)$ & $22(4 \cdot 9)$ & $3(0 \cdot 7)$ & $10(2 \cdot 2)$ & $443(35.8)$ & $384(86 \cdot 7)$ & $45(10 \cdot 2)$ & $10(2 \cdot 3)$ & $4(0.8)$ \\
\hline Village & $96(7 \cdot 7)$ & $70(72 \cdot 9)$ & $19(19 \cdot 8)$ & $3(3 \cdot 1)$ & $1(1 \cdot 0)$ & $3(3 \cdot 2)$ & $96(7 \cdot 8)$ & $82(85 \cdot 4)$ & $14(14 \cdot 6)$ & & \\
\hline Rural & $69(5 \cdot 5)$ & $47(68 \cdot 1)$ & $9(13 \cdot 0)$ & $6(8 \cdot 7)$ & $4(5 \cdot 8)$ & $3(4 \cdot 4)$ & $68(5 \cdot 5)$ & $60(88 \cdot 2)$ & $6(8.9)$ & & $2(2 \cdot 9)$ \\
\hline
\end{tabular}

TABLE II -Responses to questions on HIV and AIDS to test doctors' knowledge. Figures are numbers (percentages) answering question

\begin{tabular}{|c|c|c|c|c|}
\hline \multirow[b]{2}{*}{ Statement } & \multirow{2}{*}{$\begin{array}{l}\text { Correct } \\
\text { response }\end{array}$} & \multicolumn{3}{|c|}{ Response of doctors } \\
\hline & & True & False & Don't know \\
\hline $\begin{array}{l}\text { Anal transmission of HIV from male to male is easier than vaginal transmission from male to female } \\
\text { HIV is less infectious than hepatitis } \\
\text { The worldwide rate of increase of HIV is slowing down } \\
\text { AIDS is not a notifiable disease } \\
\text { Current feeling is that } 15 \% \text { or so of patients positive for HIV will go on to get full blown AIDS }\end{array}$ & $\begin{array}{l}\text { True } \\
\text { True } \\
\text { False } \\
\text { True } \\
\text { False }\end{array}$ & $\begin{array}{r}1007(79 \cdot 7) \\
863(69 \cdot 7) \\
102(8 \cdot 1) \\
755(60 \cdot 4) \\
475(38 \cdot 4)\end{array}$ & $\begin{array}{r}211(16 \cdot 7) \\
263(21 \cdot 2) \\
1007(79 \cdot 9) \\
344(27 \cdot 5) \\
615(49 \cdot 7)\end{array}$ & $\begin{array}{r}45(3 \cdot 6) \\
113(9 \cdot 1) \\
152(12 \cdot 1) \\
152(12 \cdot 2) \\
148(12 \cdot 0)\end{array}$ \\
\hline $\begin{array}{l}\text { The number of people in United Kingdom known to have AIDS in October } 1987 \text { was: } 0-100,100-500,500-1000,1000-1500 \text {, } \\
1500-2500,2500-5000,5000-10000,>10000\end{array}$ & $\begin{array}{l}\text { Correct } \\
\text { answer. } \\
1000-1500\end{array}$ & $\begin{array}{c}\text { Correct } \\
280(23 \cdot 1)\end{array}$ & $\begin{array}{l}\text { Within one } \\
\text { range } \\
579(47 \cdot 7)\end{array}$ & $\begin{array}{c}\text { Wrong } \\
3.54(29 \cdot 2)\end{array}$ \\
\hline
\end{tabular}

TABLE III - Factors significantly associated with higher knowledge scores about HIV and AIDS among general practitioners

\begin{tabular}{lccc}
\hline Factor & $\begin{array}{c}\text { Partial regression } \\
\text { coefficient }\end{array}$ & Standard deviation & p Value \\
\hline Qualified at United Kingdom medical school & 1.379 & $0 \cdot 226$ & \\
Year of qualifying & 0.034 & $0 \cdot 006$ & \\
Training state & 0.522 & $0 \cdot 197$ & 0.008 \\
Logarithm of No of patients with HIV & 0.177 & 0.074 & 0.017 \\
\hline
\end{tabular}

reflected awareness of the illness and indicated doctors' educational state and further needs. The attitudinal questions were chosen to reflect various views about HIV, AIDS, and their relevance to general practitioners. A third of the general practitioners questioned did not reply. The respondents were representative in terms of distribution of practices, trainers, and membership of the Royal College of General Practitioners.

Women were overrepresented in the sample. They

TABLE IV - Results of attitudinal questions. Figures are numbers (percentages) answering question

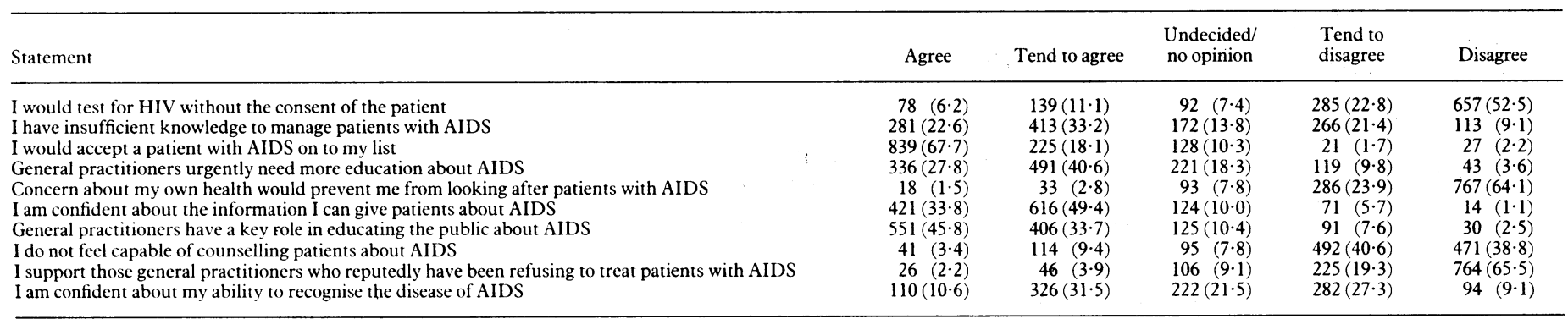


TABLE V-Significant association of attitudes to HIV and AIDS and variables among general practitioners

\begin{tabular}{|c|c|c|c|}
\hline Statement & Significant variables & $\chi^{2}$ & $\mathrm{p}$ Value \\
\hline I would test for AIDS without the consent of the patient & $\left\{\begin{array}{l}\text { MRCGP } \\
\text { Year qualified } \\
\text { No of patients with HIV seen } \\
\text { Knowledge score }\end{array}\right.$ & $\begin{array}{r}16 \cdot 41 \\
9 \cdot 68 \\
6 \cdot 32 \\
5 \cdot 58\end{array}$ & $\begin{array}{l}0 \cdot 0001 \\
0 \cdot 0019 \\
0 \cdot 0119 \\
0 \cdot 0181\end{array}$ \\
\hline I have insufficient knowledge to manage patients with AIDS & $\left\{\begin{array}{l}\text { Year qualified } \\
\text { No of patients with AIDS seen } \\
\text { Type of practice } \\
\text { Sex } \\
\text { Knowledge score } \\
\text { MRCGP }\end{array}\right.$ & $\begin{array}{r}36 \cdot 35 \\
15 \cdot 03 \\
6 \cdot 14 \\
5 \cdot 48 \\
4 \cdot 70 \\
4 \cdot 03\end{array}$ & $\begin{array}{l}0 \cdot 0001 \\
0 \cdot 0001 \\
0 \cdot 0132 \\
0 \cdot 0192 \\
0 \cdot 0301 \\
0 \cdot 0446\end{array}$ \\
\hline Concern about my health would prevent me from looking after patients with AIDS & $\left\{\begin{array}{l}\text { United Kingdom graduate } \\
\text { Unmarried } \\
\text { Knowledge score } \\
\text { No of patients with HIV seen } \\
\text { Year qualified }\end{array}\right.$ & $\begin{array}{r}26 \cdot 84 \\
14 \cdot 07 \\
6 \cdot 10 \\
4 \cdot 84 \\
4 \cdot 67\end{array}$ & $\begin{array}{l}0.0001 \\
0.0002 \\
0.0135 \\
0.0278 \\
0.0308\end{array}$ \\
\hline I don't feel able to counsel patients about AIDS & $\left\{\begin{array}{l}\text { No of patients with AIDS seen } \\
\text { MRCGP }\end{array}\right.$ & $\begin{array}{l}9 \cdot 84 \\
4 \cdot 59\end{array}$ & $\begin{array}{l}0 \cdot 0017 \\
0.0322\end{array}$ \\
\hline $\begin{array}{l}\text { I support those general practitioners who reputedly have been refusing to treat patients } \\
\text { with AIDS }\end{array}$ & $\left\{\begin{array}{l}\text { Unted Kingdom graduate } \\
\text { Unmarried } \\
\text { Knowledge score } \\
\text { Sex } \\
\text { No of patients with AIDS seen }\end{array}\right.$ & $\begin{array}{r}11 \cdot 77 \\
10 \cdot 17 \\
8 \cdot 03 \\
7 \cdot 77 \\
5 \cdot 02\end{array}$ & $\begin{array}{l}0.0006 \\
0.0014 \\
0.0046 \\
0.0053 \\
0.0251\end{array}$ \\
\hline I would accept a patient with AIDS on to my list & $\left\{\begin{array}{l}\text { United Kingdom graduate } \\
\text { Type of practice } \\
\text { No of patients with AIDS seen } \\
\text { Being a trainer } \\
\text { Unmarried }\end{array}\right.$ & $\begin{array}{r}16 \cdot 49 \\
10 \cdot 42 \\
7 \cdot 45 \\
7 \cdot 27 \\
4 \cdot 53\end{array}$ & $\begin{array}{l}0 \cdot 0001 \\
0 \cdot 0012 \\
0 \cdot 0060 \\
0 \cdot 0070 \\
0 \cdot 0334\end{array}$ \\
\hline General practitioners urgently need more education about AIDS & $\left\{\begin{array}{l}\text { Being a trainer } \\
\text { Sex } \\
\text { No of patients with AIDS seen } \\
\text { United Kingdom graduate } \\
\text { Year qualified }\end{array}\right.$ & $\begin{array}{r}14 \cdot 10 \\
11 \cdot 26 \\
11 \cdot 14 \\
9 \cdot 89 \\
7 \cdot 46\end{array}$ & $\begin{array}{l}0 \cdot 0002 \\
0 \cdot 0008 \\
0 \cdot 0008 \\
0 \cdot 0017 \\
0 \cdot 0063\end{array}$ \\
\hline I am confident about the information I can give patients about AIDS & $\left\{\begin{array}{l}\text { No of patients with HIV seen } \\
\text { Knowledge score } \\
\text { Year qualified }\end{array}\right.$ & $\begin{array}{r}10 \cdot 72 \\
9 \cdot 78 \\
5 \cdot 01\end{array}$ & $\begin{array}{l}0.0011 \\
0.0018 \\
0.0252\end{array}$ \\
\hline General practitioners have a key role in teaching the public about AIDS & $\left\{\begin{array}{l}\text { Knowledge score } \\
\text { No of patients with AIDS seen }\end{array}\right.$ & $\begin{array}{l}7 \cdot 65 \\
5 \cdot 89\end{array}$ & $\begin{array}{l}0.0057 \\
0.0152\end{array}$ \\
\hline I am confident about recognising the illness of AIDS & $\left\{\begin{array}{l}\text { No of patients with HIV seen } \\
\text { Type of practice }\end{array}\right.$ & $\begin{array}{r}19 \cdot 48 \\
5 \cdot 60\end{array}$ & $\begin{array}{l}0 \cdot 0001 \\
0 \cdot 0179\end{array}$ \\
\hline
\end{tabular}

TABLE VI - Variation of demography, knowledge, and attitudes with place of qualification (agree and tend to agree combined, disagree and tend to disagree combined). Figures are numbers (percentages)

\begin{tabular}{|c|c|c|c|}
\hline & Response & $\begin{array}{l}\text { United Kingdom } \\
\text { graduates }\end{array}$ & $\begin{array}{l}\text { Overseas } \\
\text { graduates }\end{array}$ \\
\hline $\begin{array}{l}\text { Inner city/urban practice } \\
\text { Seen patients with HIV } \\
\text { Member of Royal College of General Practitioners }\end{array}$ & & $\begin{array}{l}548(48 \cdot 6) \\
369(32 \cdot 5) \\
470(41 \cdot 2)\end{array}$ & $\begin{array}{r}77(70 \cdot 6) \\
21(18 \cdot 9) \\
9(8 \cdot 1)\end{array}$ \\
\hline Would test for HIV without consent of patient & $\left\{\begin{array}{l}\text { Disagree } \\
\text { Unsure } \\
\text { Agree }\end{array}\right.$ & $\begin{array}{r}864(77 \cdot 0) \\
74(6 \cdot 6) \\
185(16 \cdot 4)\end{array}$ & $\begin{array}{l}66(59 \cdot 4) \\
18(16 \cdot 2) \\
27(24 \cdot 4)\end{array}$ \\
\hline Would accept patient with AIDS on to list & $\left\{\begin{array}{l}\text { Disagree } \\
\text { Unsure } \\
\text { Agree }\end{array}\right.$ & $\begin{array}{rr}42 & (3 \cdot 8) \\
90 & (8 \cdot 1) \\
984 & (88 \cdot 2)\end{array}$ & $\begin{array}{l}5(4 \cdot 7) \\
34(31 \cdot 8) \\
68(63 \cdot 5)\end{array}$ \\
\hline Possible effects of HIV on self prevents providing care to patients & $\left\{\begin{array}{l}\text { Disagree } \\
\text { Unsure } \\
\text { Agree }\end{array}\right.$ & $\begin{aligned} & 980(90 \cdot 5) \\
& 66(6 \cdot 1) \\
& 36(3 \cdot 4)\end{aligned}$ & $\begin{array}{l}62(62 \cdot 7) \\
24(24 \cdot 2) \\
13(13 \cdot 1)\end{array}$ \\
\hline Supports doctors who refuse to care for patients with AIDS & $\left\{\begin{array}{l}\text { Disagree } \\
\text { Unsure } \\
\text { Agree }\end{array}\right.$ & $\begin{aligned} 918(87 \cdot 2) \\
79(7 \cdot 5) \\
56(5 \cdot 3)\end{aligned}$ & $\begin{array}{l}60(60 \cdot 6) \\
24(24 \cdot 2) \\
15(15 \cdot 2)\end{array}$ \\
\hline
\end{tabular}

thought that general practitioners needed more education about AIDS $(p=0.0008)$ and also tended to support general practitioners who refused to treat patients with AIDS. This tendency was shared by married doctors, who in addition were more concerned about their own health and less likely to accept patients with AIDS on to their lists than unmarried doctors. These findings presumably reflect their preoccupation with family responsibilities, motives that may also explain the differences between the sexes.

Foreign graduates were underrepresented in the survey, but tables V and VI showed clear differences between their attitudes, knowledge scores, and practice demography and those of the United Kingdom graduates. Those who replied were presumably more interested in the survey or had views that they were happier to reveal than the non-respondents. It may be inferred that non-responding foreign graduates would have had views that were less knowledgeable and more negative than their colleagues who did reply. Some inferences may be drawn by comparing the foreign and United Kingdom graduates. Firstly, factors in the medical education in the United Kingdom may instil a different set of attitudes and a better knowledge base than those provided by medical schools abroad. Teaching varies with culture and patterns of indigenous disease, but it would be impossible to break my figures down further as the numbers from each global region were so small. Secondly, the foreign group yielded more undecided replies than the United Kingdom group-for instance, $90(8 \cdot 1 \%)$ United Kingdom graduates were undecided whether to accept patients with AIDS on to their lists whereas the figure for foreign graduates was $34(32 \%)$. This may reflect a reluctance to commit themselves or genuine indecision owing to lack of knowledge or experience. In many ways this was encouraging as suitable education should help the undecided doctors learn more about AIDS and develop more helpful attitudes about it.

Another finding was that though a higher proportion 
of foreign graduates worked in inner city practices $(71 \% v 49 \%)$, a smaller proportion had seen patients positive for HIV. This may reflect their own definitions of inner city or may mean that they are recognising fewer cases. Possibly, patients of those general practitioners refer themselves directly to hospitals. Further work would be needed to ascertain the true explanation.

Members of the Royal College of General Practitioners were less likely than non-members to test for HIV without the patient's consent and had one or two attitudes that were somewhat more positive, but year of qualification seemed to be a better marker of both knowledge and attitudes. Table $\mathrm{V}$ showed that knowledge score and the year of qualification were significantly associated; the score was higher for more recently qualified doctors. The same was seen with attitudes; younger doctors were less likely to test for HIV without the patient's consent and thought that they had more knowledge about AIDS but also thought that general practitioners need more information. Younger doctors seemed to have a better understanding of HIV and less hostile attitudes towards patients with AIDS than their older colleagues. Such findings were expected among the youngest principals, who had been educated in the AIDS era, but there was a gradient throughout the age range. Possibly recent medical education allows doctors to assimilate new ideas more readily than in the past or maybe attitudes harden with age.

Trainers had significantly better results in the knowledge questions than non-trainers and were happier about accepting patients with AIDS on to their lists. They also thought, however, that general practitioners needed more education about AIDS, an attitude that could indicate either deficiency in the present provision of knowledge or a welcome desire for more knowledge among those already teaching. Over $6 \%$ (71) of respondents supported those general practitioners who were reputedly refusing to treat patients with AIDS, and over 9\% (103) were undecided, so that almost one doctor in six would at least consider such an option. Most doctors, however, gave responses that indicated a positive attitude towards HIV and AIDS.

Most respondents thought that general practitioners had an important part to play in educating patients about the syndrome, though confidence about recognising AIDS was more evenly split. Experience of patients positive for HIV and those with AIDS conferred some benefit to the doctors. They were more likely to accept patients on to their lists and were confident about their knowledge but also thought that general practitioners needed more education about AIDS.

As far as information is concerned the professional journals were the most quoted primary sources with government circulars coming second and unclassified sources third; thus more articles about the disease, more guidelines from the government, and broader coverage of the country by organisations such as the Terrence Higgins Trust would raise doctors' awareness. Television programmes featured low on the list of source material, but sources were not listed in the questionnaire and it was left to the respondent to name them. This did not, of course, preclude doctors from entering the answers that they thought were expected.

Finally, it is worth comparing this survey with another one of all general practitioners in Edinburgh, which has a particular problem of HIV infection associated with use of drugs. ${ }^{9}$ The response rate was $77 \%$, and the doctors yielded more uniform results in all topics, with higher knowledge scores overall. Their attitudes were similar to those in the United Kingdom as a whole. Either they were all better informed or their education had been more thorough and more evenly distributed. Proximity to patients with HIV and AIDS may well be the best stimulus to learning, but further studies on the Edinburgh general practitioners' sources of information may help the United Kingdom as a whole.

I am grateful to Mr Richard Wakeford, Mrs Linda Archer Dr Carol Jagger, Mr Jeremy Walsh, of Walsh Marketing, and everyone at the general practice unit in University of Leicester for their help. I also acknowledge a grant from the Health Promotion Research Trust.

1 Russell MAH, Wilson C, Taylor C, Baker CD. Effects of general practitioners advice against smoking. Br Med f 1979;ii:231-5.

2 Dover C. Lock up victims of AIDS, urges a doctor. Daily Express 1986 Nov 4:2 (col 4).

3 Milne RIG, Keen SM. Are general practitioners ready to prevent the spread of HIV? Br.Med f 1988;296:533-5.

4 Anderson P, Mayon-White R. General practitioners and management of infection with HIV. Br Med f 1988;296:535-7.

5 Boyton R, Scambler G. Survey of general practitioners' attitudes to AIDS in the North West Thames and East Anglian regions. Br Med f 1988;296:538-40.

6 Searle ES. Knowledge, attitudes and behaviour of health professionals in relation to AIDS. Lancet 1987; i:26-8.

7 Anonymous. GP trainers and trainees [Editorial]. Br Med f 1982;284: 1420

8 Department of Health and Social Security. Health and personal social services statistics for England. London: HMSO, 1985:51-2.

9 Robertson JR, Bucknall ABV, Welsby PD, et al. Epidemic of AIDS related virus (HTLV-3/LAV) infection among intravenous drug abusers. Br Med $\mathcal{J}$ 1986;292:527-9.

(Accepted 18 April 1989)

\section{CLINICAL CURIO}

\section{Acute acquired methaemoglobinaemia after amyl nitrite poisoning}

A 16 year old girl was found drowsy, incoherent, and deeply cyanosed. Her blood pressure was $120 / 50 \mathrm{~mm} \mathrm{Hg}$ and pulse rate 88 beats/minute. An arterial blood sample with room air was dark chocolate brown, and analysis showed that the $\mathrm{pH}$ was $7 \cdot 31$, carbon dioxide tension $4.5 \mathrm{kPa}$, oxygen tension $11 \cdot 2 \mathrm{kPa}$, bicarbonate concentration $16.5 \mathrm{mmol} / \mathrm{l}$, and base excess $-8.5 \mathrm{mmol} / \mathrm{l}$. The calculated saturation was $95 \%$, which seemed unlikely and was $63 \%$ when measured on an oximeter. Methaemoglobin concentration was 33\%. She was given $6 \mathrm{ml}$ of $1 \%$ methylene blue intravenously $(1 \mathrm{mg} / \mathrm{kg})$, and in 10 minutes the cyanosis resolved and she regained consciousness. She said that she had swallowed amyl nitrate given to her in a night club. She was given activated charcoal. Within one hour the blood gas tensions were virtually normal, and methaemoglobin concentration was $1 \cdot 4 \%$.

Amyl nitrate is no longer used as a coronary vasodilator but is often abused for "recreational" purposes' by sniffing. Many compounds, including nitrites, cause methaemoglobinaemia by oxidising the iron moiety in haemoglobin ${ }^{2}$ so that the haemoglobin cannot carry oxygen, and the symptoms of methaemoglobinaemia are the same as those of hypoxia. Methylene blue in the presence of methaemoglobin reductase reduces methaemoglobin non-enzymatically to normal haemoglobin. ${ }^{+}$In standard blood gas analyses oxygen saturation is calculated from the oxygen and carbon dioxide tensions and $\mathrm{pH}$ assuming the haemoglobin and its dissociation curve are normal. This may be misleading if haemoglobin is present in an abnormal form such as methaemoglobin or carboxyhaemoglobin. Clinical hypoxaemia and the severity of the metabolic acidosis are greater than expected owing to the increased oxygen affinity of the remaining functionary haem groups in the presence of methaemoglobin. ${ }^{5}-\mathrm{J}$ M T PIERCE, M S NIFISEN, Department of Anaesthetics, Southampton ( $r$ Hospital, Southampton SO9 4XY

1 Laaban JP, Bodenan P, Rochemaure J. Amyl nitrite poppers and methemoglobinaemia. Ann Intern Med 1985;103:804.

2 Wintrobe NM, Lee GR, Roger DR. Clin hematologv. 8th ed. Philadelphia: Lee and Febiger, 1981:1011-8.

3 Hall AH, Kulig KW, Rumack BH. Drug and chemical induced methaemoglobinaemia. Clinical features and management. Med Toxicol Adverse Drug Exp 1986;1:253-60.

4 Tada K, Tokayi A, Odaka Y, et al. A resuscitation puzzle: acute acquired methemoglobinemia. Crit Care Med 1987;15:614-5.

5 Daling RC, Roughton FJW. The effect of methemoglobin on equilibrium between oxygen and hemoglobin. Am f Physiol 1942;137:56. 